\title{
KONSTANTYN FILOZOF, CZYLI KTO?
}

\author{
Constantine the Philosopher, Who Was He?
}

\author{
Marian Andrzej Wesoły
}

DOI: 10.17846/CL.2020.13.2.22-34

\begin{abstract}
WESOŁY, Marian Andrzej. Constantine the Philosopher, Who Was He? This outstanding historical figure who died 1151 years ago on February 14, 869, has become known in history under a different name, often known without the eloquent epithet of 'philosopher', but with the added religious dignity of St. Cyril. He is usually compared to his elder brother St. Methodius, and they are nowadays commonly referred to as the Apostles to the Slavs, although today hardly anyone knows that their original names were Konstantinos and Michael. There is extensive literature on the importance of these Thessalonian brothers for the creation of the Slavic alphabet (Glagolitic) and the translation from Greek of the liturgical offices. The literature includes mainly religious, philological and historical perspectives, but there are only few philosophical and historiosophical considerations. In respect of the mentioned anniversary of Constantine - St. Cyril, we will reflect on his philosophical education, views and discussions with various interlocutors.
\end{abstract}

Keywords: Constantine the Philosopher, Methodius, first teachers of the Slavs, enkyklios paideusis, Byzantine philosophy

Odrzekt mu tedy Filozof: dar to wielki dla tych, co go potrzebuja, a dla mnie nie ma nic większego od nauki, przez którą zyskując mądrość czci i bogactwa chce szukać pradziada.

Posłaliśmy ci tego, komu Bóg te [litery słowiańskie] objawił, męża czcigodnego i prawowiernego, miłośnika ksiąg i filozofa.

Przyjmij dar ten, co cenniejszy i lepszy od wszelkiego srebra i złota, i drogocennych kamieni, i przemijającego bogactwa.

Żywot Konstantyna IV 15; XIV 18 (tłum. moje M.W.)

Znakomita postać, od śmierci której mija ponad 1150 lat (zm. 14 luty 869), przeszła do historii pod innym imieniem, z pominięciem wymownego epitetu 'Filozof', lecz z przydaniem religijnej godności 'Świętego'. Bywa on zestawiany ze swym starszym bratem, także 'Świętym', znanym potocznie też pod innym imieniem. Takie bowiem były przybrane imiona zakonne owych braci z Tesalonik (Sołunia): Kyrillos (Cyryl) i Methodios (Metody), zwanych potocznie w naszych czasach 'Apostołami Słowian', chociaż dziś mało kto wie, że ich oryginale imiona brzmiały: Konstantinos (Konstantyn) i Michael (Michał). Kojarzy się ich z ewangelizacją, misją religijną 
czy nawracaniem, jednak żadne z tych określeń nie występuje w dokumentach źródłowych, gdzie Konstantyn Filozof nazywany jest pierwszym nauczycielem ludu słowiańskiego, a Metody - ojcem i mistrzem naszym, arcybiskupem morawskim.

$\mathrm{Na}$ ich temat jest obszerna literatura przedmiotu, ujęta głównie w wymiarze religijnym, historycznym i filologicznym ${ }^{1}$, wszelako niewiele $\mathrm{w}$ tym szerszego rozpoznania perspektywy filozoficznej czy historiozoficznej ${ }^{2}$. Stworzenie od podstaw słowiańskiego alfabetu (głagolicy i cyrylicy) oraz przekład z greki ksiąg liturgicznych, to wiekopomne dziedzictwo braci Sołuńskich, o którym ogólnie wiadomo, lecz mało znane i docenione jest to, że Konstantyn był z wykształcenia i powołania filozofem. Dlaczego jego postać nie widnieje w wykładni historii filozofii bizantyńskiej czy średniowiecznej? Czyż nie można w ogóle określić jego poglądów filozoficznych i działalności na ich podstawie? Fakt, że nie tworzył tekstów filozoficznych, nie wyklucza go z tej dziedziny, skoro też inni niczego nie pisali, jak Sokrates, Pirron czy Karneades, choć mają zaszczytne miejsce w dziejach filozofii europejskiej.

Konstantyn jako filozof skazany był na zapomnienie zapewne dlatego, że właściwe rozpoznanie i docenienie filozofii greckiej krzewionej w Bizancjum nastąpiło dopiero w drugiej połowie XX wieku i jako nowa dziedzina historiografii nadal wymaga gruntownych studiów ${ }^{3}$. Tak więc autorzy większości prac o Konstantynie - Cyrylu w zasadzie nie byli zainteresowani wykładnią filozofii bizantyńskiej, jako też sami jej nieliczni badacze nie uwzględniali tegoż Konstantyna, gdyż uchodził on za misjonarza religijnego ${ }^{4}$.

Rozpoznajmy więc w źródłach racje uznania Konstantyna za jego życia Filozofem, nie tylko przez jego rodaków, ale i Saracenów, Chazarów, Żydów i Słowian. Podstawowym źródłem jest Żywot Konstantyna i Żywot Metodego - powstałe wkrótce po ich śmierci w języku i środowisku słowiańskim. Te najstarsze teksty tego piśmiennictwa, niebędące przekładem z grecki, tchną żywym wspomnieniem o tych światłych i zasłużonych nauczycielach Słowian.

W Żywocie Konstantyna zwany on jest Filozofem prawie 70 razy, a raz tylko Cyrylem, gdy przed swą śmiercią przyjął takie imię zakonne. Tak samo wymowne jest nazywanie go Filozofem prawie 10 razy w nieco późniejszym Żywocie Metodego, napisanym wkrótce po jego śmierci (885). Konstantyn, choć młodszy od Metodego przynajmniej o dekadę i krócej żyjący (ok. 827-869), w obydwu tych tekstach stawiany jest na pierwszym miejscu i z wymownym epitetem Filozof. Z kolei Metody, jak czytamy w jego Żywocie (IV), gotów był umrzeć za wiarę chrześcijańską, służąc bratu młodszemu modlitwą, a ten jako Filozof nauczaniem pokonywał przeciwników.

Bliskim czasowo wyciągiem obydwu tych żywotów słowiańskich jest pochodny dokument łaciński, zwany Legendą włoską - Legenda Italica. W tym zwięzłym tekście Konstantyn jako Filozof wzmiankowany jest 12 razy, choć wątki biograficzne dotyczące braci Sołuńskich są tutaj na drugim planie.

Z kolei w słowiańskiej Mowie pochwalnej na cześć świętych Cyryla i Metodego chodzi już o uczczenie tych postaci jako świętych i przesławnych nauczycieli ludu słowiańskiego. Konstantyn jako Filozof wspomniany jest tylko raz, i to w takiej wzniosłej duchowej stylizacji:

1 Podstawowe pozycje w literaturze obcej to: Grivec -Tomšič (1960), Dvornik (1970), Bernstein (1984), Tachiaos (2001). Z ważniejszych polskich opracowań: Lehr-Spławiński (1967), Naumow (1985), Leśny (1987), Moszyński (1988), Gajek - Górka (1991), Wójtowicz (2000).

2 Na temat pojęcia filozofii według Konstantyna - Cyryla nieliczne są artykuły: Ševčenko (1956), Dostál (1966), Schütz (1985; 1990), Dupkala (2009), Gulevska (2012), Zozulaková (2016), Lukoviny (2017).

3 Pionierska była La philosophie byzantine Bazyla Tatakisa (1949 - polski przekład z moim posłowiem 2012). Zob. najnowsze opracowanie G. Kaprieva z przeglądem bibliografii: Brungs - Kapriev - Mudroch (2019).

4 W Posłowiu do polskiego przekładu dzieła Tatakisa (277-28) umieściłem Konstantyna Filozofa w zestawie filozofów w Bizancjum. Podobnie uczynił także Ján Zozulak $(2016,55)$. 
„Młodszym z urodzenia był błogosławiony Konstantyn, który przez umysł i cnoty wysoko w górę niczym orzeł wzlatywał na skrzydłach ducha. Oświecony boskim światłem rozumu stał się narzędziem wybranym Ducha Świętego (Dz 9, 15.17) i przezeń jaśniejąc wszelką wiedzą filozofów okazał się skarbnicą niewyczerpaną." (tłum. A. Naumow).

Jeszcze w Liście papieża Hadriana II Gloria in excelsis Deo (868-969) Konstantyn widnieje jako błogosławiony filozof, natomiast w późniejszych dokumentach papieskich znika już jego imię, gdyż rzecz dotyczy głównie jego brata Metodego ${ }^{5}$. Poniżej jeszcze wrócimy do wczesnych utworów słowiańskich, w których Konstantyn wspominany jest jako filozof, lecz wpierw rozpoznajmy dane biograficzne o jego usposobieniu duchowym, edukacji i powołaniu filozoficznym.

Jak czytamy w Żywocie Konstantyna [III], jako siedmioletni chłopiec w proroczym śnie wybrał on Mądrość (Sophia) na umiłowaną towarzyszkę życia. Otóż imię Sophia stało się w Bizancjum prawosławnym symbolem w wymownej nazwie świątyni Hagia Sophia, nie tylko zresztą w Konstantynopolu (Święta Mądrość - trafniej dosłownie tak tłumaczyć, niż potocznie Mądrość Boża).

W tym też duchu od wczesnej młodości był on pod wpływem ksiąg Grzegorza Teologa z Nazjanzu, którego czytał i wpajał pamięciowo uznając za swego „mistrza i oświeciciela”. Ten żyjący pięć wieków wcześniej (ok. 320 - 390), wybitny Ojciec Kościoła, uważał wykształcenie (paideia) za najwyższe dobro, jakie osiągamy w życiu. Jak wspominał w Opowieści o swoim życiu

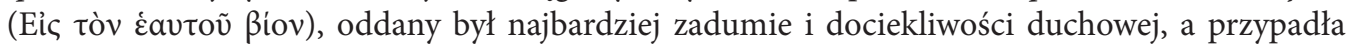
mu działalność publiczna sprawiała niewdzięczność i przygnębienie. Zauważmy analogiczne usposobienie duchowe młodego Konstantyna, który poświecił się księgom i nauce, a przypadnie mu nader wymagająca służba cesarzowi.

Pragnąc dalej kształcić się w dziedzinie gramatyki (tj. w studiach literackich), nie zdołał znaleźć nauczyciela w ojczystym Sołuniu. Dzięki zaś wsparciu logotety (sekretarza cesarskiego) Teoktysta udał się na studia do Carogrodu (słowiańska nazwa Konstantynopola). Tam od połowy IX wieku po przezwyciężeniu ikonoklazmu następuje polityczna i kulturowa konsolidacja Cesarstwa. To czasy, jak podają historycy, „świtu nowego humanizmu” (Tatakis, Lemerle), za sprawą wybitnych erudytów, bibliofilów, oraz odrodzenia świeckiej edukacji (enkyklios paideusis), czyli kształcenia w zakresie trivium (gramatyka, retoryka, dialektyka/logika) oraz quadrivium (geometria, arytmetyka, astronomia, muzyka). Powołano też działalność stołecznej wszechnicy (pandidakērion) w pałacu cesarskim Magnaura, gdzie zwieńczeniem studiów wyższych było prawo, medycyna i filozofia.

Takie wykształcenie uzyskał Konstantyn w krótkim czasie, jak czytamy w jego Żywocie [IV], że „wyuczył się Homera i geometrii u Leona i u Fotiosa dialektyki i wszystkich nauk filozoficznych, nadto zaś retoryki, arytmetyki, astronomii i muzyki, i wszystkich innych sztuk helleńskich. A wszystkie te nauki tak opanował, jakby się tylko jednej uczył. Bystrość bowiem łączyła się z pilnością, jedna drugą przemagając, przez co doskonalą się nauki i sztuki." (tłum. T. Lehr-Spławiński).

Otóż Leon (ok. 790 - 869) i Focjusz (ok. 810/820 - 893) to dwaj znakomici nauczyciele Konstantyna, dzięki którym mógł on wykształcić się na światłego filozofa. Nie wiemy, kiedy i gdzie studiował on u Leona, zwanego też wymownie Matematykiem czy Filozofem ${ }^{6}$. Zauważmy u Leona i Konstantyna analogiczne dążenie do wiedzy. Leon kształcił się najpierw w Konstantynopolu, lecz zainteresowany szczególnie matematyką udał się do pewnego mistrza na wyspie Andros i tam też zdobył fachowe i rzadkie księgi. Potem prywatnie nauczał, a jeden z jego uczniów

5 Odsyłamy do dokumentów papieskich zebranych w przekładzie polskim w: Gajek - Górka (Część 2, 1991).

$6 \quad$ Na temat Leona Matematyka zob. P. Lemerle (1971); T. A. Senina (2017). 
będąc $\mathrm{w}$ niewoli saraceńskiej popisał się przed kalifem (zapewne Al-Mutasimem) świetną znajomością geometrii, nabytą u Leona. Wówczas kalif miał zaprosić Leona na swój dwór z ofertą sowitego wynagrodzenia, lecz ten odmówił, a w nagrodę cesarz Teofil zaoferował mu nauczanie (ekpaideutērion) przy kościele Czterdziestu Męczenników. Potem Leon awansował na arcybiskupa Tesalonik (840 - 843), lecz wkrótce został odsunięty jako przeciwnik kultu ikon, tak jak jego krewny i patriarcha Jan Gramatyk. Dalej nauczał on we wszechnicy pałacu cesarskiego Magnaura, który miał wyposażyć w różne wynalazki techniczne, jak drzewa z ruchomymi ptakami, ryczące lwy i lewitujący cesarski tron. Był wynalazcą optycznego telegrafu z użyciem świateł na wielkie odległości (od Konstantynopola do Tarsos w Cylicji).

W Leonie miał więc młody Konstantyn wzór niezwykłego miłośnika ksiąg, uczonego w matematyce, astronomii i medycynie, ale też w literaturze i poezji (zachowały się jego epigramy). Konstantym miał kształcić się u niego w tej właśnie dziedzinie geometrii i poezji.

Tak samo, a może jeszcze więcej, Konstantyn zawdzięczał znakomitemu mistrzowi Focjuszowi, u którego uczył się dialektyki i zespołu dziedzin filozoficznych. Focjusz bowiem najbardziej interesował się logiką i dialektyką Arystotelesa, którego nader cenił za realizm poznawczy, w czym zapewne zgadzał się także sam Konstantyn. Zanim został patriarchą, Focjusz przeczytał, streścił i ocenił w celu dydaktycznym ogromną liczbę ksiąg (270 tzw. kodeksów, nazwanych potem Biblioteką). Rozliczne pisma Focjusza świadczą o jego niebywałej erudycji i zacięciu pedagogicznym z troską o filozoficzną i teologiczną edukację młodzieży?

Był to wytrawny uczony i dyplomatą, któremu dwukrotnie przypadło być światłym patriarchą (858 - 867; 877 - 886) Konstantynopola, choć wiązało się to z narosłymi konfliktami. W liście do papieża Mikołaja I ( $\mathrm{z}$ roku 861) Focjusz żali się z tego powodu, że po wyborze na patriarchę zmieniło się jego życie, oderwany został od kręgu swych uczniów i dyskutantów, narażając się na nieprzyjemności, zawiść i niezrozumienie.

W teologii Focjusz był wierny tradycji soborów powszechnych i pentarchii, czyli władzy pięciu wielkich patriarchatów. Jako patriarcha głosił homilie, rozsyłał listy i przesłania w spornych sprawach kościelnych, określił przymioty i cnoty sprawiedliwego władcy, relacje między cesarstwem a patriarchatem. Wszelako to jego osoba i podjęte decyzje stały się osią konfliktu z papieżem w sprawie prymatu Rzymu, chrystianizacji Bułgarii i Moraw, a także w kwestii dogmatycznej Filioque, co doprowadziło do schizmy (w 867 r.).

W tym wszystkim z braku świadectw niejasny jest stosunek Konstantyna Filozofa do swego mistrza Focjusza. Być może niezależnie od ich ewentualnych sporów oraz kolei losu jeden dla drugiego był „nader trwałym przyjacielem” (fortissimus amicus), jak to podaje Anastazy Bibliotekarz ${ }^{8}$.

W każdym razie Focjuszowi głównie zawdzięczał Konstantyn swą świetną formację filozoficzną. Dodajmy, że Focjusz wykształcił później także cesarza Leona VI (886 - 912), któremu też przypadł zaszczytny epitet Filozof.

Przytoczmy teraz, jak odpowiedział Konstantyn na pytanie logotety Teoktysta: „Filozofie, chciałbym się dowiedzieć, co to jest filozofia. On zaś bystrze mu zaraz odpowiedział: Jest to zrozumienie rzeczy Boskich i ludzkich, w jakim stopniu może się człowiek zbliżyć do Boga i jak uczy się przez działanie stawać się na obraz i podobieństwo Stwórcy swego. Odtąd tym bardziej polubił go i stale zapytywał o wszystko ten mąż tak znakomity i czcigodny. A on wykładał mu filozofię, wielkie myśli w niewielu słowach wypowiadając." (Żywot Konstantyna, IV 8, Lehr-Spławiński 1967).

Jest to najważniejsze świadectwo, które należy rozumieć w kontekście ówczesnej edukacji filozoficznej. To wczesny okres filozofii bizantyńskiej, odziedziczonej po antycznej, jeszcze sprzed

Na temat Focjusza zob. Lemerle (1971); Dvornik (1967; 1970; 1974); Kapriev (2019).

8 Zob. Lukoviny (2015); Garzaniti (2015). 
sporami wokół tzw. teologii mistycznej i apofatycznej9. Tradycyjnie dzielono filozofię na teoretyczną obejmującą teologię, fizykę i matematykę, oraz praktyczną w zakresie etyki, ekonomii i polityki. W znaczeniu zaś bardziej określonym filozofię pojmowano dość szeroko zgodnie z tradycją szkół neoplatońskich w Atenach i Aleksandrii. U schyłku V wieku Ammonios w Komentarzu do Isagogi (2.22-9.24) Porfiriusza wyszczególnił sześć określeń filozofii, powtarzanych i przez innych egzegetów (Jan Damasceński, Dawid, Elias). Są one następujące:

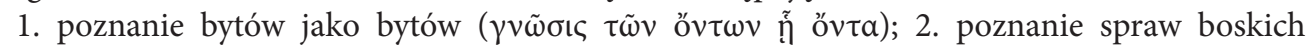

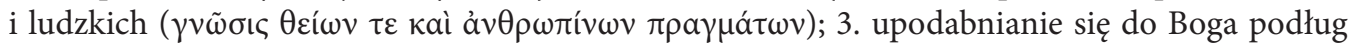

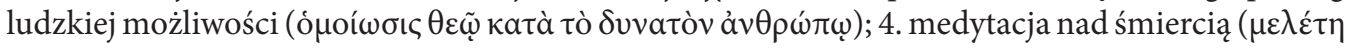

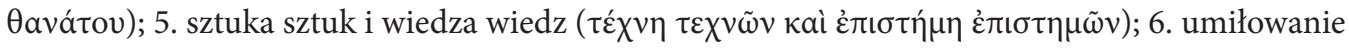
mądrości ( $\varphi \imath \lambda i ́ a ~ \sigma o \varphi i ́ a \varsigma)$.

To ostatnie, najogólniejsze pojęcie (6) powtarza sens samej nazwy. Z pozostałych zaś jedne pochodzą od Arystotelesa (1 i 5), drugie (3 i 4) od Platona, a trzecie (2) od stoików. Choć z tych różnych określeń filozofii niektóre wykluczały się wzajemnie, to nie pozostawały w sprzeczności z chrystianizmem, a najbardziej odpowiadały tej duchowości pojęcia (3 i 4), w wersji raczej neoplatońskiej.

Z powyższego wynika, że Konstantyn pojmował filozofię w znaczeniu (2) i (3), z dodaniem chrześcijańskiego sensu działania na obraz i podobieństwo Stwórcy. Tak jak starał się on ujmować poznawanie nauk i sztuk w scalającej jedności, tak też w filozofii „wyrażać wielkie myśli w niewielu słowach.” Świadczy to o ścisłym i racjonalnym jego podejściu w duchu Arystotelesa i Focjusza.

Teoktyst zachwycony zdolnościami swego protegowanego oferował mu uzyskanie bogactw, intratny ożenek i zaszczytny urząd stratega, lecz ten odmówił w myśl swego powołania w filozofii: „dar to wielki dla tych, co go potrzebują, a dla mnie nie ma nic większego od nauki, przez którą zyskując mądrość czci i bogactwa chcę szukać pradziada”.

Odpowiedź ta jest wymowną oznaką osobowości Konstantyna Filozofa, podobnie też ocenionego przez cesarza Michała III, który wyśle go z krzewieniem pisma słowiańskiego na Morawy (zob. podane na wstępie motto).

Następnie za wstawiennictwem Teoktysta u cesarzowej Teodory młodemu Konstantynowi przypadł zaszczytny stołecznego urząd kustosza (chartophykas) przy patriarsze u Świętej Mądrości. Jednakże wkrótce schronił się potajemnie w monastyrze nad Bosforem (zapewne Kleidon), skąd po pół roku odszukano go i nakłoniono, by „przyjął katedrę nauczycielską i nauczał filozofii rodaków i cudzoziemców z pełną powagą i [urzędowym] poparciem. I tego się podjął” (tłum. Lehr-Spławiński 1967).

Niestety niczego nie wiemy o tym jego oficjalnym nauczaniu i uczniach w tym zakresie. W każdym razie (ok. 850 roku) jeszcze w młodym wieku zasłynął Konstantyn jako znakomity filozof; musiał być oddanym wykładowcą w krzewieniu mądrości na chwałę bożą, na miarę wielkiego dzieła cesarza Konstantyna.

W rozpoznaniu Konstantyna jako filozofa, wobec niewielu danych, trzeba uwzględnić to, w jaki sposób i w jakich kwestiach ujawnia się on jako wytrawny dyskutant i polemista. W jego Żywocie znajdujemy kilka takich zdarzeń dyskusyjnych w różnych miejscach i z różnymi rozmówcami. Są to m. in.: Jan Gramatyk, Saraceni, Chazarzy, Żydzi, biskupi i duchowni w Wenecji.

I tak z inicjatywy samego cesarza młody Konstantyn podjął polemikę z odsuniętym za ikonoklazm patriarchą Janem Gramatykiem. Zwycięska i chyba publiczna dysputa młodego filozofa z dumnym starcem na temat żywej i spornej nadal sprawy kultu ikon musiała wywrzeć niemałe wrażenie, choć okoliczności tego nie są nam znane.

9 Zob. Ierodiakonou - Zografidis (2010); Brungs - Kapriev - Mudroch (2019). 
Tak jak Focjusz dzięki swej niebywałej erudycji, nawet wbrew własnej woli, podjął się być patriarchą, tak też Konstantyn dzięki swej sławie uczonego filozofa, wciągnięty został do służby cesarskiej w trzech nader dalekich i uciążliwych misjach ekumenicznych, w trzech różnych kierunkach geopolitycznych, najpierw (855 - 856) do Agarienów (Saracenów) na południowym Wschodzie, potem (860 - 961) do Chazarów na północnym Wschodzie, i jeszcze (864 - 869) do Słowian na Wielkie Morawy na północnym Zachodzie (zob. na mapie prawdopodobne trasy ogromne odległości do pokonania w każdą stronę):

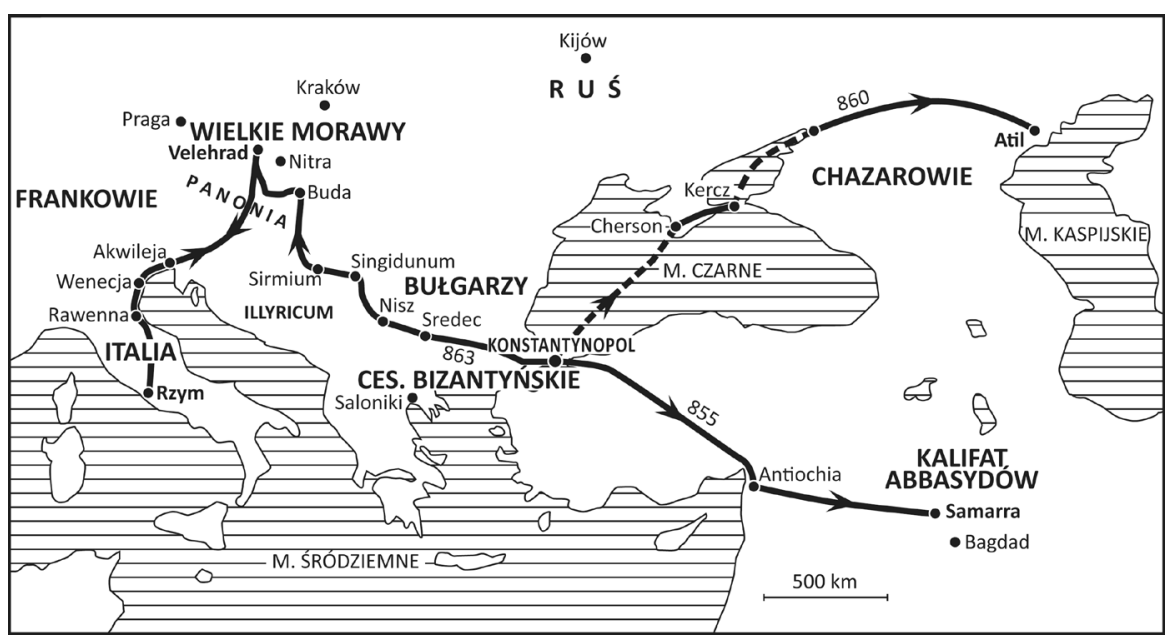

Saraceni wyznający islam zwrócili się do cesarza o wyjaśnienie niedorzecznego według nich dogmatu Trójcy Świętej. Konstantyn Filozof dla obrony wiary chrześcijańskiej z radością zgodził się wystąpić w cesarskim poselstwie, w którym uczestniczył tajny radca (asikrit) i chyba także Focjusz, ale nie brat Konstantyna Metody ${ }^{10}$. Udało się ono zapewne do Samarry nad Tygrysem, nowej i zamożnej stolicy Abbasydów za kalifa Al-Mutawakilla (847 - 861). Konstantyn dyskutował tam ze światłymi rozmówcami i odważnie przeciwstawił głębię wiary chrystusowej płytkiemu wyznaniu proroka Mahometa. Opowiadał na wszystko ze znawstwem, a zapytany, skąd tyle wszystkiego wie, orzekł, że to od nas (tj. od Greków) wywodzą się wszelkie sztuki i umiejętności.

Po powrocie $\mathrm{z}$ tej dalekiej misji dla Konstantyna przykrym niewątpliwie przeżyciem było zabójstwo logotety Teoktysta (856), stąd wycofał się on do monasteru na górze Olimp, gdzie przebywał jego starszy brat Metody. Zmienił się układ władzy (regencja Bardasa) i Focjusz został patriarchą (588), ale braciom Sołuńskim przypadnie teraz wielkie ekumeniczne wyzwanie.

Na prośbę Chazarów o przysłanie uczonego męża, który by pokonał w rozprawie Żydów i Saracenów, „abyśmy przyjęli wiarę waszą”, cesarz Michał III odszukał Konstantyna Filozofa i odprawił go wraz z bratem Metodym do Chazarów, aby wyłożył im chrześcijański dogmat Trójcy Świętej”.

W Żywocie Konstantyna [VIII-XII] najdłuższa partia tekstu to relacja z poselstwa do Chazarow, które dla Filozofa było nader cenne poznawczo, gdyż w Chersonie miał wyuczyć się mowy żydowskiej i przełożyć na grekę jej gramatykę, poznać też księgi samarytańskie, a także Ewangelie i Psałterz pisane literami 'roskimi', który to język miał też sobie przyswoić11. Ponadto miał tam

10 Zob. Dvornik (1967).

11 Rzecz niejasna i dyskutowana, zob. Tachiaos (2001). 
odnaleźć szczątki św. Klemensa, które później przekazał w Rzymie papieżowi Hadrianowi II z wielką czcią i uznaniem dla swojej osoby.

Podczas pobytu u Chazarów przypadło Filozofowi odpowiadać na pytania dotyczące zwyczajów w cesarstwie, mądrości ksiąg i pism, także na pytania samego kagana, który odnosił się doń z respektem, gdyż chodziło mu o rozstrzygnięcie, która wiara najlepsza jest ze wszystkich. Natomiast dysputa z Żydami była długa i zawzięta wokół racji starego i nowego Zakonu. To ciekawe świadectwo ówczesnej konfrontacji wyznaniowej z judaizmem. W większości odpowiedzi Konstantyn powoływał się na biblijne przypowieści, ale i rzekł w sposób filozoficzny: „Ogniem sprawdza się złoto i srebro, a człowiek rozumem odcina fałsz od prawdy” (38). Filozof ukazywał wyższość chrystianizmu nad islamem i judaizmem, jednak misja ta nie powiodła się i Chazarowie ostali przy judaizmie.

Po powrocie do Konstantynopola wrócił Filozof do zacisznego życia wśród ksiąg i modłów, lecz wkrótce przypadła mu nowa i wyczerpująca posługa misyjna. Jeśli poprzednio Saracenom i Chazarom chodziło raczej o objaśnienie i poradę teologiczną, to teraz (863) do cesarza Michała III zwrócił się Rościsław, książę Wielkich Moraw, z prośbą o przysłanie im biskupa i nauczyciela, którzy by głosili prawdziwą wiarę chrześcijańską w mowie zrozumiałej dla Słowian, aby „widząc to inne kraje, do nas się upodobniały".

Ze strony Rościsława była to rozgrywka dyplomatyczna, aby zmyślnie przeciwstawić się dominacji papieskiej i frankońskiej na Morawach, podobnie jak w tym samym czasie między Rzymem a Konstantynopolem rzecz rozgrywał Borys, chan Bułgarii. W tej złożonej sytuacji geopolitycznej cesarz jednak nie posłał na Morawy biskupa, licząc się bardziej z odzyskaniem strefy wpływów w chrystianizowanej Bułgarii. Poselstwu zaś Rościsława uroczyście opowiedział, że wysyła mu „miłośnika ksiąg i filozofa”, którego dar głoszenia w mowie słowiańskiej prawdziwej wiary jest cenniejszy od wszelkich skarbów, a droga prawdy służy zbawieniu i upamiętnieniu na miarę wielkiego dzieła cesarza Konstantyna (zob. podane na wstępie motto).

Misja Konstantyna i Metodego do Chazarów i Morawian przypadła na czasy pierwszego patriarchatu Focjusza (858 - 867), gdy doszło do schizmy (867) z papieżem Mikołajem i dramatycznej rywalizacji Rzymu i Konstantynopola o chrystianizację Bułgarii i Moraw. Jednak w pismach Focjusza i w innych greckich brak wzmianki o misji morawskiej braci Sołuńskich, co przecież nie oznacza, że rola tego patriarchy nie była tutaj znacząca ${ }^{12}$.

Pomijamy jednak te kwestie, jak i inne związane ze stworzeniem przez Konstantyna oryginalnego alfabetu słowiańskiego dla przekładu z greki ksiąg liturgicznych. Ważne zaś w naszym temacie jest to, w jaki sposób Konstantyn odpierał w Wenecji zarzuty stawiane mu przez zebranych tam biskupów i duchownych łacińskich, którzy „napadli nań jak kruki na sokoła”, że naucza w nieprawym języku. Ujawnił się on znów jako filozof, mimo iż jego adwersarze tak go tutaj nie nazywają, a tylko wyzywająco w ten sposób:

„Człowiecze, powiedz nam, jak mogłeś teraz stworzyć dla Słowian pismo i uczysz go, czego nikt pierwej nie wynalazł [...] my zaś wiemy tylko o trzech językach, którymi przystoi w piśmie Boga chwalić: hebrajskim, greckim i łacińskim." (tłum. Lehr-Spławiński).

Następuje dłuższa i żywa polemika Konstantyna w sprawie tej „trójjęzycznej herezji”, pomysłowo wsparta biblijną i filozoficzną argumentacją. Najpierw podaje on argument z porządku naturalnego i zwyczajowego, że przecież deszcz od Boga pada równo na wszystkich, takoż i słońce na wszystkich świeci. Wiele też obcych ludów chwali Boga w swoim języku, jak np. Ormianie, Persowie, Abazgowie itd. Głoszenie więc Ewangelii należne jest wszystkim ludziom i objawienie Słowa Bożego winno być słyszane i rozumiane.

12 Zob. Dvornik (1974); Ivanov (2003); Garzaniti (2015). 
Na rzecz tego poglądu parafrazuje Konstantyn partie z listu św. Pawła do Koryntian (14, 5-33; 37-40). Choć duch może się modlić w niezrozumiałej mowie, ale przy tym umysł pozostaje jałowy. „W kościele wolę pięć słów wymówić z rozumem, aby i innych pouczyć, niż tysiące wygłosić w nieznanym języku." Dostrzegamy w tym racjonalne i pedagogiczne podejście filozofa w krzewieniu nauki i prawosławnej wiary.

Jak czytamy w Żywocie Konstantyna [XVI], „tymi słowy i lepszymi jeszcze zawstydził ich i odszedł, pozostawiając ich wszystkich". Papiestwo najpierw przychylne liturgii słowiańskiej na Morawach, potem wskutek interwencji niemieckiego duchowieństwa zdecydowanie jej zakazało (w roku śmierci Metodego - 885 roku). Jednak szczęśliwym trafem obrządek słowiański krzewiony był w Bułgarii, a dalej na Rusi, tworząc doniosłe dziedzictwo cyrylo-metodiańskie.

Najstarszym bodaj utworem poetyckim Słowian jest Proglas - wstęp do Ewangelii, przypisywany samemu Konstantynowi Filozofowi. Jest to manifest uświęconego słowa słowiańskiej mowy i nauki danej od Boga. Wymowa tego współbrzmi w planie ideowym z Żywotem Konstantyna, który jako filozof „wielkie myśli w niewielu słowach wyrażał”. Zacytujmy takie wymowne wyimki z tego tekstu (w przekładzie A. Naumowa 1985, 32):

„Więc posłuchajcie wszyscy Słowianie:

dar to jest przecież od Boga dany,

dar Boży dany dla części prawej,

dar duszom, który nigdy nie tleje,

tym duszom wszystkim, co go przyjmują.” [...]

„Bo święty Paweł rzekł nauczając:

Modlitwę swoją oddając Bogu

Wole powiedzieć słów pięć zaledwie,

Byleby wszyscy bracia pojęli,

Niż niepojętych dziesięć tysięcy.

I jakiż człowiek tego nie pojmie?

Któż przypowieści nie uzna mądrej,

Która nam daje prawe nauki." [...]

„Lecz niech dorzucę i ja przypowieść,

by w słowach rzecz mądrość wielką:

nagie są bowiem bez ksiąg narody,

a bez oręża nie mogą walczyć

z tym, co dusz naszych jest przeciwnikiem,

w niewolę wiecznych mąk paść gotowi.”

Innym wczesnym utworem, inspirowanym żywotami braci Sołuńskich, jest anonimowy Kanon, który opiewa Cyryla Filozofa i błogosławionego Metodego. Z Pieśni III taki fragment (w przekładzie A. Naumowa 1985, 54):

„Drabiną wybraną się stałeś, Filozofie, Boga głoszący, przez swoje jasne nauki wszystkich do nieba wiodąc.

Żyjąc na ziemi jak anioł, o Konstanty, pełen mądrości, słusznie zostałeś nazwany nauczycielem wszystkich." 
Ponadto z Pieśni V te wersy opiewające Filozofa (s. 57);

„Mądrość filozofów czerpałeś

Z głębiny tajemnic Bożych

I nimi olśniony, mędrcze,

Słowo zaniosłeś narodom nowym.”

I jeszcze dłuższy anonimowy utwór poetycki Służba ku czci Świętego Cyryla jako „wspomnienie o świętym ojcu naszym Konstantynie Filozofie, co przybrał imię Cyryla, nauczyciela narodu słowiańskiego". Oto wymowny fragment z Pieśni VI (s. 125):

„Od młodości miłując mądrość

wybrałeś siostrę Mądrość prawdziwą

i wciąż rosła twa mądrość w Bogu,

i stałeś się mędrcem i filozofem."

Dodajmy, że z misją Konstantyna i Metodego na Morawach zbiegły się też początki chrystianizacji Bułgarów, ale Rusów i to w kolejnych etapach. Znamienne jest to, że właśnie na Rusi najbardziej poczytne bywały Żywoty braci Sołuńskich, skoro stamtąd pochodzą niemal wszystkie zachowane ich manuskrypty. Tam też najbardziej krzewiona była żywa tradycja cyrylo-metodiańska pisma słowiańskiego (gramota slovienskaja) i nauczania książkowego (uczenije kniżnoje) ${ }^{13}$.

Świadczy o tym dobitnie Opowieść o przełożeniu ksiąg na język słowiański zawarta w Powieści minionych lat $[11]^{14}$. Otóż Słowianie stanowiący jeden naród, gdy byli już ochrzczeni, nie znając grecki ani łaciny, zwrócili się do cesarza Michała o przysłanie nauczyciela, który by im „wyłożył słowa ksiąg i ich znaczenie”. Czytamy tam, że „,cesarz Michał wezwał wszystkich filozofów i przekazał im wszystko, co powiedzieli kniaziowie słowiańscy. I rzekli filozofowie: 'Jest w Salonikach mąż, imieniem Leon; jego dwaj synowie są mądrymi filozofami.”' (podkreślenie moje - M. W.).

Chodziło oczywiście o Konstantyna i Metodego, lecz w tej wersji pojawiają się 'filozofowie' (w liczbie mnogiej), a dalej mowa o ułożeniu alfabetu słowiańskiego i przełożeniu ksiąg kościelnych oraz sprzeciwu przeciwko temu i reakcji papieża rzymskiego. Kronikarz ruski wprawdzie błędnie podaje, że Konstantyn miał potem nauczać naród bułgarski, lecz wymowa ideowa tej opowieści jest taka, że naród słowiański i ruski stanowi jedno we wspólnym dziedzictwie języka i ksiąg przełożonych z greki.

Co więcej, dalej w Powieści minionych lat [36-42] w związku z chrystianizacją Rusi powraca postać greckiego filozofa i 'nauczania w księgach'. Po przybyciu do kniazia Włodzimierza Bułgarów z ofertą wiary mahometańskiej, Niemców z Rzymu od papieża i Żydów chazarskich, potem Grecy przysłali doń filozofa, który, aby przekonać kniazia do przyjęcia chrystianizmu greckiego, wygłasza przed nim długą i uczoną opowieść o stworzeniu świata, wygnaniu z Raju Adama i Ewy, zabójstwie Abla, potopie i wieży Babel, o Abrahamie, o Mojżeszu i prorokach, a dalej o Chrystusie, którego od nauki apostołów przyjęli Grecy w swej wierze.

Znamienne jest to, że występuje tu nie nazwany z imienia właśnie filozof grecki. Nie ma wątpliwości, że był on szacownym symbolem, wzorem greckiego uczonego, miłośnika ksiąg i mądrości na wzór Konstantyna Filozofa. Na koniec dla kniazia Włodzimierza w przyjęciu chrztu decydująca była nie tylko opowieść greckiego filozofa, ale i urok greckiej liturgii z relacji poselstwa ruskiego. Czytamy o tym w Powieści minionych lat [42]:

13 Na ten temat zob. D. Obolensky, 1997.

14 Fragmenty z Powieści minionych lat podajemy w przekładzie F. Siedleckiego (1999). 
„I przyszliśmy tedy od Greków, i wiedli nas, gdzie służą Bogu swojemu, i nie wiedzieliśmy, w niebieli byliśmy, czy na ziemi: nie ma bowiem na ziemi takiego widowiska ni piękna takiego, i nie wiemy, jak opowiedzieć o tym, tylko to wiemy, że tam Bóg z ludźmi przebywa, i nabożeństwo ich jest najlepsze ze wszystkich krajów. My zaś nie możemy zapomnieć piękna tego, każdy bowiem człowiek, gdy skosztuje słodkości, później gorzkości nie przyjmuje, jako i my nie możemy tu żyć."

Ponadto greckim dziedzictwem Konstantyna Filozofa było też to, że po chrzcie Rusów Włodzimierz „posyłał też zbierać u znakomitszych ludzi dzieci, i dawać na naukę w księgach” (uczenije kniżnoje). Wychowany w takiej formacji duchowej został także jego syn Jarosław, zwany stąd „Mądrym”, gdyż lubił księgi i czytał je w nocy i we dnie, promował przekłady ksiąg greckich i płynące z nich nauki. Rozliczne księgi składał on we wzniesionej cerkwi Świętej Sofii w Kijowie. Oto wymowne słowa z Powieści minionych lat [59]:

„Wielki bowiem bywa pożytek z nauki książkowej, przez księgi bowiem napominani i pouczeni jesteśmy o drodze do pokuty, mądrość bowiem zyskujemy i wstrzemięźliwość przez słowa ksiąg, gdyż te są rzekami napawającymi wszystek świat, są źródłami mądrości; w księgach bowiem jest głębina niezmierzona, przez nie wszak w smutku pocieszani jesteśmy, one są wędzidłami wstrzemięźliwości." (tłum. F. Sielicki).

Tak więc przetrwało w świadomości Słowian stworzenie przez Konstantyna alfabetu słowiańskiego i przełożenie z greki Pisma świętego jako dzieło miłośnika ksiąg i uczonego filozofa. Wspominany on był z dumą i czczony w pamięci potomnych jako pierwszy nauczyciel ludu słowiańskiego. Mnich Chrabr (1 poł. X w.) podaje, że nieliczni tylko z uczonych greckich wiedzą o pochodzeniu ich pisma i ksiąg. „Natomiast jeśli zapytasz słowiańskich uczniów, mówiąc: kto wam litery wymyślił: czy kto księgi przełożył? - to wszyscy wiedzą i odpowiadając rzekną: święty Konstantyn Filozof zwany Cyrylem, on to nam litery wymyślił i księgi przełożył, a także Metody brat jego, apostoł słowiański. Jeszcze żywi bowiem ci, którzy ich widzieli.” (tłum. A. Naumow).

Wszelako osobliwe jest to, że od imienia zakonnego Cyryla nazwano w następstwie 'cyrylicą' alfabet, którego on przecież nie był twórcą. Stworzony przez Konstantyna Filozofa genialnie od podstaw alfabet stanowiła 'głagolica'. Cyrylica tak nazwana dla uczczenia pamięci tego Filozofa została stworzona później w ośrodku ochrydzkim na podstawie liter alfabetu greckiego przez skrybów przyzwyczajonych do pisania tym alfabetem ${ }^{15}$.

Tak jak Leon Matematyk i patriarcha Focjusz, tak i Konstantyn Filozof należał do najbardziej światłych postaci tamtych czasów. Konstantyn i jego starszy brat Metody nie byli z powołania misjonarzami, nie mieli święceń kapłańskich, pierwszy był chyba tylko diakonem, a drugi igumenem w monasterze. Metody sprawował urząd archonta w prowincji zamieszkałej przez Słowian, lecz wcześnie wycofał się do monasteru Polychron na górze Olimp w Bitynii. Zasłużony też w misji do Chazarów otrzymał od patriarchy Focjusza propozycję sakry biskupiej, lecz odmówił i powrócił do swego monasteru. Potem misja na Morawach stała się dlań głównym powołaniem życiowym i wiekopomną zasługą. Konstantyn na łożu śmierci zachęcił brata Metodego, aby nie wracał do ulubionego monasteru, a tylko ciągnął dalej swe nauczanie Słowian.

Konstantyn natomiast był z powołania i zamiłowania uznanym filozofem. Niezrównany w dysputach zapragnął mądrości ksiąg, choć dwukrotnie schronił się w monasterze, polecenia cesarskie wypełnił wzorcowo. Jak sam rzekł cesarzowi przed misją na Morawy, że choć zmęczony i schorowany, pójdzie tam z radością. A na łożu śmierci miał rzec: „Odtąd nie jestem już sługą cesarza, ani nikogo na ziemi, ale tylko Boga Wszechmogącego. I byłem i będę na wieki. Amen.” Wyczerpany trzema długimi podróżami, przeżył tylko 42 lata, a pochowany został uroczyście w rzymskim kościele św. Klemensa. To w ogóle rzadki przypadek, aby słynny za życia filozof

15 Dokładniej o tym zob. Wójtowicz, 2000. 
został po śmierci błogosławionym (blažen, gr. beatus, łac. makarios) czy świętym (podówczas nie odróżniano beatyfikacji od kanonizacji).

Jako uczony i filozof Konstantyn nie miał sobie równych w ówczesnym świecie łacińskiego Rzymu i frankońskiego Zachodu, ani w wymiarze filozofii ani w projekcie czy woli chrystianizacji Słowian w ich uświęconym języku.

Cesarstwo Konstantynopola odegrało wiekopomną rolę w inkulturacji ludów słowiańskich na Bałkanach i na Rusi, które poprzez stworzenie im alfabetu i przekłady z greki ksiąg nie tylko liturgicznych, przyswajały wysoce rozwiniętą cywilizacją materialną i duchową, dzięki wpływowi której ich rodzima kultura rozwinęła się wcześniej i prężniej niż w obrębie słowiańszczyzny zachodniej. Wszelako podział chrześcijańskiego na kościół rzymskokatolicki i prawosławny stał się fatalny dla słowiańskiej tożsamości kulturowej i miał bolesne konsekwencje dla wszystkich ludów słowiańskich. Wiążą się z tym pośmiertne i dramatyczne losy dziedzictwa cyrylo-metodiańskiego w przejawach tępienia tożsamości prawosławnej, czego nie sposób tutaj przedstawić.

Dość wspomnieć, że dopiero po jedenastu wiekach, następuje rehabilitacja zasług braci Sołuńskich w skali ekumenicznej, głównie dzięki encyklice papieskiej Grande Munus (1880) Leona XIII, który kanonizował braci Sołuńskich. W stulecie tego wydarzenia (1980) Jan Paweł II ogłosił Cyryla i Metodego „współpatronami Europy” (obok św. Benedykta). Następnie papież ten ogłosił doniosłą encyklikę Slavorum Apostoli (1985) pod znakiem jubileuszu 1100-lecia śmierci św. Metodego.

W tym wszystkim jednak niewystarczająco podkreśla się fakt, że przecież ten, kto stworzył Słowianom alfabet i zainicjował przekłady ksiąg liturgicznych był z powołania i zamiłowania greckim filozofem; tak bardzo bowiem zasłużył się w wierze prawosławnej, że został niemal wymazany z pamięci w typowo greckim wymiarze filozofii, która przecież wzbogacała chrystianizm swym intelektualnym zapleczem duchowym.

Dlatego szczególnym upamiętnieniem i docenieniem tej wiekopomnej postaci w wymiarze edukacyjnym jest nazwanie od ćwierć wieku (1996) słowackiej uczelni: Univerzita Konštantína Filozofa v Nitre - Constantine the Philosopher University in Nitra. Tam też od 2008 roku wychodzi szacowne czasopismo: Konstantínove listy / Constantine’s Letters - poświęcone badaniom nad cyrylo-metodiańskim dziedzictwem kulturowym.

Jest to dla mnie szczególnym zaszczytem z okazji jubileuszu 1151-lecia od śmierci Konstantyna - św. Cyryla móc przedłożyć w tym czasopiśmie docenienie go jako filozofa.

\section{REFERENCES}

Bernstein, Samuil Borisovich. 1984. Константин-философ и Мефодий [Constantine the Philosopher and Methodius]. Moscow.

Brungs, Alexander - Kapriev, Georgi - Mudroch, Vilem (eds.). 2019. Die Philosophie des Mittelealters, Band 1: Byzanz. Judentum. Schwabe Verlag.

Dostál, Antonín. 1966. Konstantin der Philosoph und das Ausmass seiner geistigen Bildung. In Byzantinische Forschungen 1, 76-91.

Dupkala, Rudolf. 2009. Filozofia antyczna i chrześcijańsko-bizantyńska w legendzie wielkomorawskiej “Żywot św. Konstantyna-Cyryla”. In Społeczeństwo i Edukacja 1, 33-42.

Dvornik, Francis. 1967. The Embassies of Constantine-Cyril and Photius to the Arabs. In To Honor Roman Jakobson. Essays on the Occasion of his Seventieth Birthday. The Hague, 569-576.

Dvornik, Francis. 1970. Byzantine Missions among the Slavs: SS. Constantine-Cyril and Methodius, New Brunswick.

Dvornik, Francis. 1970. The Photian Schism: History and Legend. Cambridge. 
Dvornik, Francis. 1974. Photius' Career in Teaching and Diplomacy. In Byzantinoislavica 34, 211 218 (reprint in: Dvornik, Francis. 1974. Photian and Byzantine Ecclesiastical Studies. London). Garzaniti, Marcello. 2015. The Constantinopolitan project of the Cyrilo-Methodian mission according to the Slavonic Lives of the Thessalonican brothers. In Cyril and Methodius: Byzantium and the World of the Slavs. Thessaloniki, 40-56.

Gajek, Jan Sergiusz - Górka, Leonard (eds.). 1991. Cyryl i Metody. Apostołowie i nauczyciele Słowian. Vol. I-II. Lublin.

Grivec, Franz-Tomšič, France. 1960. Constantinus et Methodius Thessalonicenses. Fontes. Zagreb. Gulevska, Valentina. 2012. The Philosophy of Constantine-Cyril and its Contribution to the Spread of the Educational Policy in the Slavic World. www.edu.uowm.gr/site/book/export/html/288.

Ierodiakonou, Katerina - Zografidis, George. 2010. Early Byzantine Philosophy. In Gerson, Lloyd P. (ed.). The Cambridge History of Philosophy in Late Antiquity. Vol. 2. Cambridge, 843-868.

Ivanov, Sergej. 2003. Византийское миссионерство: Можно ли сделать из - «варвара» христианина? [Cultural History of Byzantine MissionaryActivities: Can a "Barbarian" be turned into a Christian?]. Moscow.

Lemerle, Paul. 1971. Le Premier humanisme byzantin. Notes et remarques sur enseignement et culture à Byzance des origines au Xe siècle. Paris, 148-176.

Leo the Mathematician and Philosopher. 2017. Сочинения. Перевод с греч., коммент., вступительная статья Т. А. Сениной (монахини Кассии) [Works in Russian translation, commentary, introductory article by T. A. Senina (nun Cassia)]. St. Petersburg.

Lehr-Spławiński, Tadeusz. 1967. Konstantyn i Metody. Zarys monograficzny z wyborem źródeł. Warszawa.

Leśny, Jan. 1987. Konstanty i Metody. Apostołowie Słowian. Poznań.

Lukoviny, Luboš. 2015. Filozofia Konštantína Filozofa solúnskeho v textoch Anastázia Bibliotekára ( $\mathrm{k}$ byzantskej náuke o duši) [Philosophy of Constantinus Philosophus Thessalonicensis in the Texts of Anastasius Bibliothecarius [on the Byzantine Doctrine of the Soul]]. In Konštantínove listy [Constantine's Letters] 8, 25-39.

Lukoviny, Luboš. 2017. Vybrané problémy filozofie Konštantína Filozofa Solúnskeho. In Byzantinoslovaca VI, 159-177.

Naumow, Aleksander. 1985. Pasterze wiernych Słowian: Cyryl i Metody. Kraków.

Moszyńki, Leszek. 1988. Apostołowie Słowian. Żywoty Konstantyna i Metodego. Warszawa.

Obolensky, Dimitri. 1997. Dziedzictwo Cyryla i Metodego na Rusi. In Kłoczowski, Jerzy (ed.). Chrześcijaństwo Rusi Kijowskiej, Białorusi, Ukrainy i Rosji (X-XVII wiek). Kraków, 55-76.

Laourdas, Vasileios - Westerink, Leendert Gerrit (eds.). 1983-88. Photii patriarchae Constantinopolitani Epistulae et Amphilochia. Vol. I-VI. Lipsiae.

Schütz, Joseph. 1985. Konstantins Philosophie und seine Bestallungsurkunde als Philosoph. In Wiener Slawistisches Jahrbuch Bd. 31, 89-98.

Schütz, Joseph. 1990. Der Dialog zwischen Kaiser Michael III. und Konstantin dem Philosophen. In Slovo 39-40, 27-35.

Ševčenko, Ihor. 1956. The definition of philosophy in the „Life of Saint Constantine”. In For Roman Jakobson: essays on the occasion of his sixtieth birthday. The Hague, 449-457.

Siedlecki, Franciszek. 1999. Powieść minionych lat. Kraków.

Tachiaos, Anthony-Emil N. 2001. Cyril and Methodius of Thessalonica: The Acculturation of the Slavs. New York.

Wesoły, Marian. 2012. „Posłowie”. In Tatakis, Bazyli. Filozofia bizantyńska. Trans. by S. Tokariew. Kraków, 255-301.

Wójtowicz, Marian. 2000. Początki pisma słowiańskiego. Poznań. 
Zozulak, Ján. 2016. Byzantská filozofia. Plzeň.

Zozulaková, Viera. 2016. Praktická filozofia v živote Konštantína a Metoda [Practical Philosophy in the Lives of Constantine and Methodius]. In Konštantínove listy [Constantine's Letters] 9/1, 149-157.

Prof. PhDr. Marian Andrzej Wesoły

The Jacob of Paradies Academy

Department of Humanities

Teatralna 25

66-400 Gorzów Wielkopolski

Poland

wesoly@amu.edu.pl 